\title{
Analysis of the repair of bone defects filled with $\beta$-tricalcium phosphate associated to pure titanium implants
}

\section{Análise do reparo de defeitos ósseos preenchidos com $\beta$-Tricálcio Fosfato associado a implantes de titânio}

\author{
Roberta Weirich Mottin* \\ Juliana Goelzer ${ }^{* *}$ \\ Roger Correa de Barros Berthold ${ }^{* * *}$ \\ Thiago Aragon Zanella ${ }^{* * * *}$ \\ Daniela Nascimento Silva ${ }^{* * * *}$ \\ Cláiton Heitz ${ }^{* * * * *}$
}

\begin{abstract}
Objective: The present study aims to develop a histological descriptive analysis on the repair of bone defects filled with $\beta-T C P$, associated to pure titanium implants into cavities prepared in the calvarial bone of rats. Materials and method: Eighteen male adult rats were randomly selected and divided into three groups of six rats each, according to their period of death: 15, 30, and 60 days. Four bone defects were made into each one of the calvarial bones of rats and filled with: (a) $\beta-T C P$, (b) clot, (c) $\beta-T C P+$ pure titanium screw, and (d) pure titanium screw. The samples were cut and histologically assessed. Presence and volume of loose connective tissue and newly formed bone tissue were analyzed, as well as the presence or absence of remaining material $(\beta-T C P)$ into the defect. Results: It was verified an acceleration bone neoformation process in the presence of $\beta$-TCP. Conclusion: The results suggest the biocompatibility and osteoconductivity of the biomaterial, even when associated to pure titanium implants.
\end{abstract}

Keywords: Biomaterials. Calcium Phosphate. Bone Substitutes.

\section{Introduction}

The repair of bone tissues damaged by traumas or pathologies, and the reconstruction of the alveolar ridge are fundamentally important in Dentistry. Although considered the golden rule for grafting, autografts require a donor site, and some complications associated to it have been reported ${ }^{1,2}$.

The defect filling is facilitated by osteconduction, which is characterized by the production of a new bone through proliferation and migration of osteocompetent cells along the conductor. Calcium phosphate ceramics bond the properties of osteoconduction, biocompatibility, and bioactivity, in addition to its manipulation facilities during surgical procedure. Nevertheless, they have low levels of resistance to impact and tensile force ${ }^{3,4}$.

By definition, only bioactive materials establish chemical bonds with the bone. $\beta$-TCP granule is an inorganic composite that presents significant osteogenic activity in the presence of mature cells ${ }^{5}$.

Master in Oral and Maxillofacial Surgery, Pontifical Catholic University of Rio Grande do Sul, Porto Alegre, Brazil.

Master in Oral and Maxillofacial Surgery, Pontifical Catholic University of Rio Grande do Sul, Porto Alegre, Brazil.

Master student in Oral and Maxillofacial Surgery, Pontifical Catholic University of Rio Grande do Sul, Porto Alegre, Brazil.

Post-graduate student in Oral and Maxillofacial Surgery, Pontifical Catholic University of Rio Grande do Sul, Porto Alegre, Brazil.

Associate Professor in Oral maxillofacial Surgery, Federal University of Espirito Santo, Vitória, Brazil.

Chairman and Professor of Oral and Maxillofacial Surgery, Pontifical Catholic University of Rio Grande do Sul, Porto Alegre, Brazil. 
Titanium is known as a biocompatible material and it is successfully used in dentistry and orthopedics. Nonetheless, bone conduction around the titanium is inferior to that around bioactive ceramics such as calcium phosphate ${ }^{6}$. The use of biomaterials, as the $\beta$-TCP, associated to commercially pure titanium implants, aims to adapt mechanical properties of metals to the bone healing properties of biomaterials ${ }^{6}$.

In the present study we performed a histological descriptive analysis of bone repair in defects filled with $\beta$-Tricalcium Phosphate, associated to pure titanium implants, regarding the osteoconductive properties of the $\beta$-TCP, and verifying if those properties are maintained when the biomaterial is associated to the titanium.

\section{Materials and method}

This study was developed according to the Ethical Principles for Experiments on Animals (protocol CEUA 08/00065). A total of 18 male adult rats, from the Rattus Norvegicus species, Wistar lineage, with average weight from 280 to $320 \mathrm{~g}$, were used in this experiment. The animals were randomly divided into three groups of six rats each according to the period of death $(15,30$, and 60 days). Four defects were made in the calvarial bone of the animals, each one of the defects representing a group: A) $\beta$ - TCP group; B) Clot group (control ); C) $\beta$ - TCP + screw group; D) Screw group.

General anesthesia was induced by intraperitoneal injection of $50 \mathrm{mg} / \mathrm{kg}(0,05 \mathrm{ml} / 100 \mathrm{~g})$ veterinary ketamine chlorhydrate (Dopalen ${ }^{\mathrm{TM}}$ VetBrands Divisão Veterinária Ltda, Jacarei, São Paulo Brazil), and $5 \mathrm{mg} / \mathrm{kg}(0,025 \mathrm{ml} / 100 \mathrm{~g})$ xylazine chlorhydrate (Anasedan $^{\mathrm{TM}}$ CEVA Santé Animale, Paulínia, São Paulo Brazil). After the vertex, the skull was shaved and disinfected, a full-thickness flap was raised to expose the skull bone. Using a spherical carbide drill $(1.5 \mathrm{~mm})$ in low rotation, under irrigation of $0.9 \%$ saline solution, two cavities were prepared in the superior portion of the parietal bone, with a 5 $\mathrm{mm}$ distance between them. Granular $\beta$-tricalcium phosphate ( $\beta$ - TCP) was placed in the left cavity and mixed with the present blood, while the right cavity (control) was filled only by the clot. Two more cavities were prepared in the most inferior portion of the parietal bone, with a $5 \mathrm{~mm}$ distance between them, with a perforation drill of $1.5 \mathrm{~mm}$ (Promm ${ }^{\mathrm{TM}}$, Porto Alegre, RS, Brazil) in low rotation. A liner was made with $\beta$ - TCP in the left cavity, and a commercially pure titanium screw compatible with the perforation drill was introduced. Finally, only one titanium screw was placed in the right cavity. The flap was stitched with a 4.0 nylon monofilament suture. Over the first post-operative period of 24 hours, $125 \mathrm{mg}$ of acetaminophen was dissolved in the water given to the rats.

After the predicted healing period of 15,30 , and 60 days, the death of the animals proceeded by isoflurane inhalation. The soft tissue of the experimental area was removed and biopsy specimens of the parietal bone, made by the four bone defects, were taken en bloc and fixed in $10 \%$ formalin.

The pieces were decalcified, dehydrated, and titanium screws were removed. A total of 4 sections/ specimen were prepared. The first section was longitudinally cut from the center of the defect, grounded to a thickness of $5 \mu \mathrm{m}$, so that each one of the segments contained two defects (with or without screw). Histological descriptive analysis of the healing of bone defects was performed by the following parameters: 1) the presence and volume of connective tissue and newly formed bone tissue; 2) the presence and absence of remaining biomaterial $(\beta-T C P)$ into the defect.

\section{Results}

An experienced pathologist previously qualified an observer to make the histological analysis.

\section{Histological Analysis}

\section{Clot group:}

15 days: Connective tissue almost filling the entire defect, and a small quantity of newly formed bone tissue was observed on the surface of the host bone.

30 days: Gradual replacement of connective tissue by the newly formed bone tissue was verified. Osteogenesis area was larger when compared to that of 15 days (Fig. 1).

60 days: Newly formed bone tissue progressed towards the center of the defect. The thickness of the newly formed bone tissue was larger when compared to that of 30 days (Fig. 2).

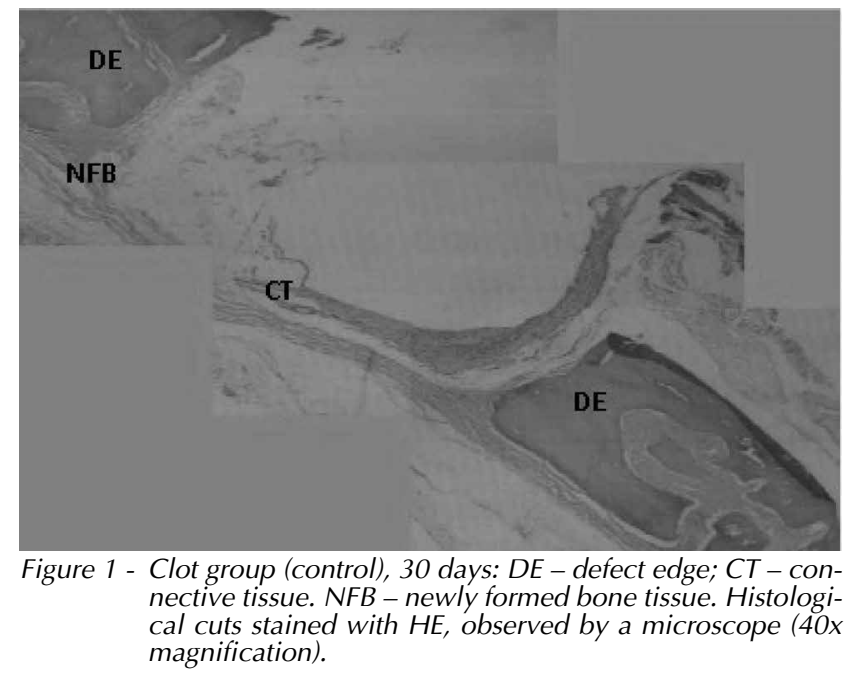




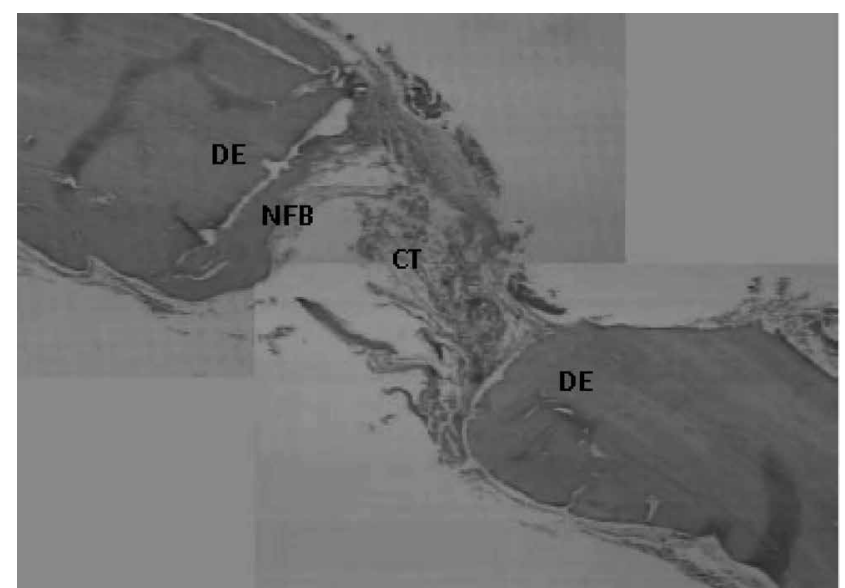

Figure 2 - Clot group (control), 60 days: DE - defect edge; $C T$ - connective tissue. NFB - newly formed bone tissue. Histological cuts stained with HE, observed by a microscope (40x magnification).

\section{$\beta$-TCP Group:}

15 days: Remaining biomaterial surrounded by connective tissue was observed, as well as intense osteoblastic activity on the defect ridges with centripetal immature bone formation.

30 days: Remaining biomaterial was surrounded by newly formed bone tissue. Immature bone along the defect ridges was thicker when compared to that of 15 days (Fig. 3).

60 days: Important centripetal progression of the newly formed bone tissue was verified, also intense osteoblastic activity in the defect central area with the remaining material surrounded by newly formed bone tissue, which almost fills the entire extension of the defect (Fig. 4).

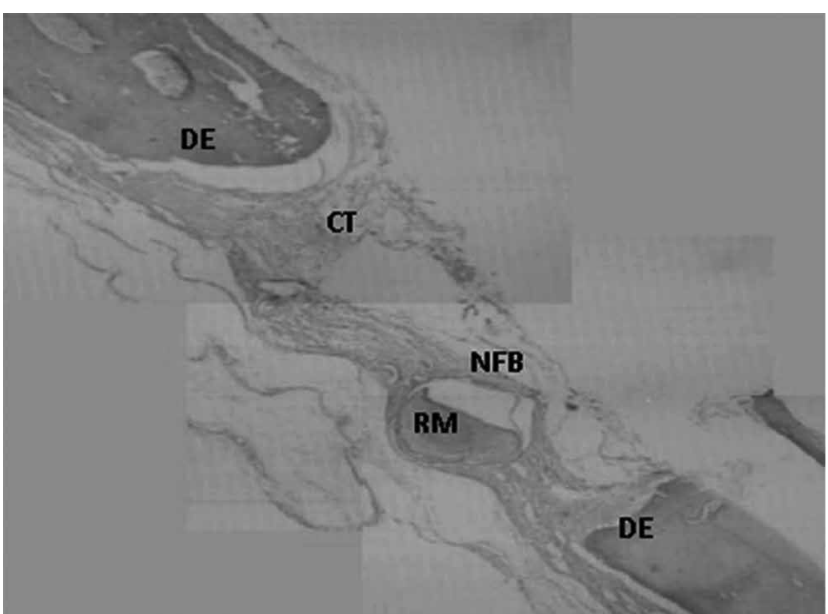

Figure 3 - $\beta$-TCP group, 30 days: DE - defect edge; CT - connective tissue RM - Remaining Material. NFB - newly formed bone tissue. Histological cuts stained with HE, observed by a microscope (40x magnification).

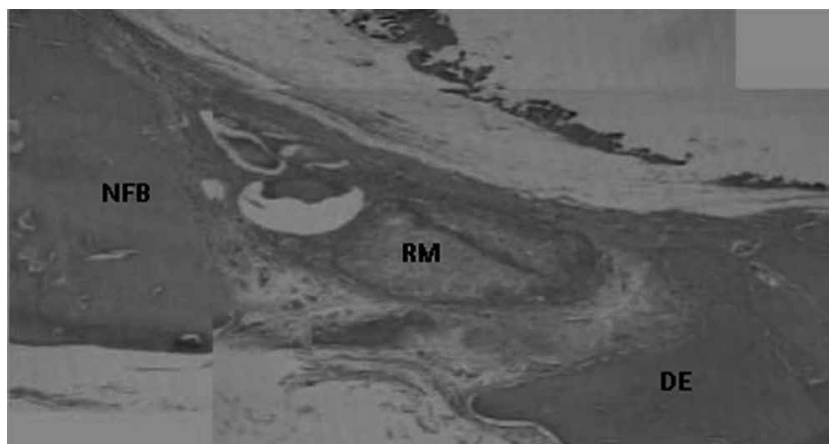

Figure 4 - $\beta$-TCP group, 60 days: $C T$ - connective tissue. $R M$ - remaining material. NFB - newly formed bone tissue. Histological cuts stained with $H E$, observed by a microscope (40x magnification).

\section{Titanium Screw Group:}

15 days: Connective tissue around the cavity previously occupied by the titanium screw was observed.

30 days: Area corresponding to the screw flange in the left extremity, with lines of immature bone formation in centripetal direction. The thickness of the connective tissue was lower when compared to that of 15 days (Fig. 5).

60 days: Immature bone formation was located in both defect extremities. Foreign body integrated to the bone tissue was present (Fig. 6).

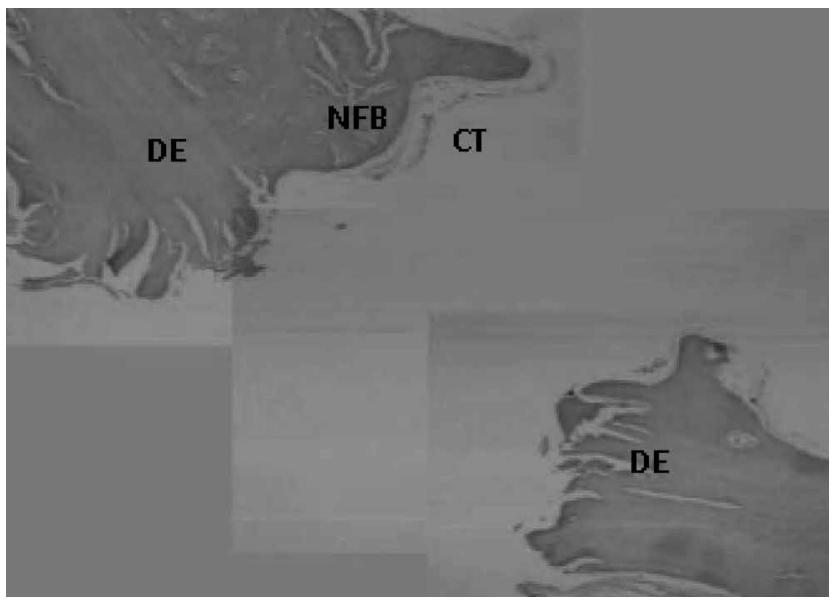

Figure 5 - Screw group (control), 30 days. DE - defect edge; CT connective tissue. NFB - newly formed bone tissue. Histological cuts stained with HE, observed by a microscope (40x magnification).

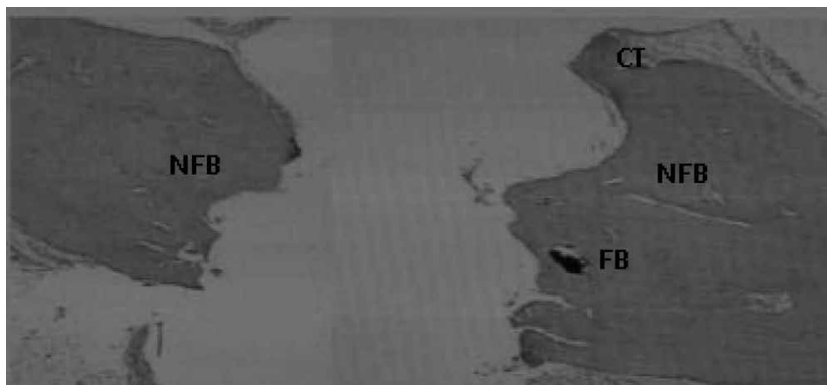

Figure 6 - Screw group (control), 60 days. CT - connective tissue. NFB - newly formed bone tissue. FB - foreign body. Histological cuts stained with $H E$, observed by a microscope (40x magnification). 


\section{Titanium Screw + $\beta$ - TCP Group:}

15 days: Area of newly formed bone tissue in both defect extremities along the remaining material.

30 days: Newly formed bone tissue growth towards the defect center (Fig. 7).

60 days: Important osteoblastic activity associated with newly formed bone tissue. The width of the cavity, previously occupied by the titanium screw, was decreased (Fig. 8).

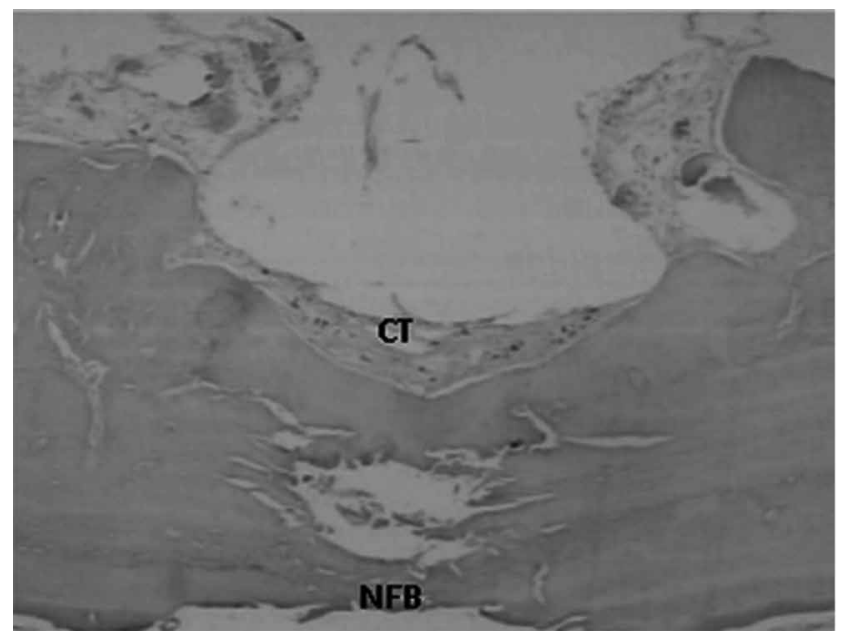

Figure 7 - $\beta-T C P+$ Screw group, 30 days. CT - connective tissue. NFB - newly formed bone tissue. Histological cuts stained with $H E$, observed by a microscope (40x magnification).

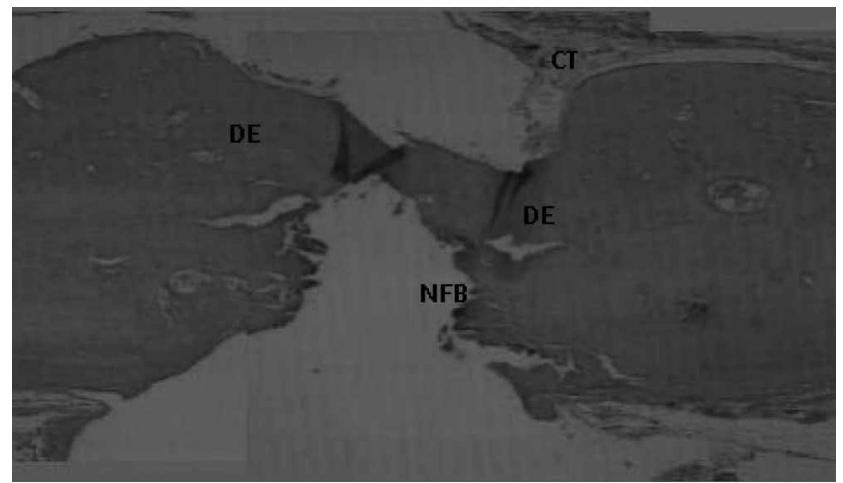

Figure $8-\beta-T C P+$ Screw group, 60 days. DE - defect edge. $C T-$ connective tissue. NFB- newly formed bone tissue. Histological cuts stained with HE, observed by a microscope (40x magnification).

\section{Discussion}

Bone graft materials are categorized in four groups: autografts, allografts, xenografts, and alloplastic ${ }^{7,8}$, having their use justified by the feature of serving as supports for bone regeneration. The disadvantages or limitations of autografts, like the need of a donor site, justify the search for alternative materials. Alloplastic or synthetic grafts, as calcium phosphate ceramics, have been presented as a viable possibility.

The present study verified that, at 15 days, the connective tissue involved the remaining $\beta$-TCP particles. This connective tissue was gradually substituted by immature bone. At this time, newly formed bone tissue was observed along the surface of the host bone, which became more pronounced at 30 days. Nevertheless, at 60 days, an invasion of the newly formed bone tissue towards the center of the defect was seen, both in $\beta$-TCP group and $\beta$-TCP + titanium screw group. Those observations suggest the biocompatibility and osteoconductivity of biomaterial, approving the findings of Yamada et al. ${ }^{1}$ (2006), Merten et al..$^{9}$ (2001), and Grandi ${ }^{10}$ (2007) who assessed two types of bioceramics $-\alpha$ tricalcium phosphate $(\alpha-$ TCP), and $\beta$ tricalcium phosphate $(\beta-$-TCP $)$ - in bone defects prepared in the calvarial bone of rats. It was observed that $\beta$-TCP granules remained in the cavity for a longer period of time, which provided the volume maintenance of the material, thus filling the defect. The authors understood that both bone substitutes have the required characteristics for clinic use. The present study verified the maintenance of $\beta$-TCP at 60 days, promoting centripetally oriented bone regeneration. Calcium phosphate was chosen for the beta phase, since it is considered the most stable phase of the material ${ }^{1,10,11}$.

Yuan et al. $^{10}$ (2002) performed a study in dogs to assess bone induction by calcium phosphate ceramics. After 2.5 years of follow-up, it was observed that the newly formed bone tissue confined inside the pores of implants remained stable. The results suggest not only the efficacy and safety of osteoinductive calcium phosphate biomaterials for clinical use, but also the possibility for further optimizing and improving osteoinductive calcium phosphate biomaterials. The bioinert nature of titanium and its alloys must be changed to bioconductivity if a strong bonding interface between implant and host bone is desired ${ }^{12}$.

Because they are bioinert, bone integration of such implants does not occur in ideal conditions ${ }^{13}$. The present study observed an association of mechanical properties of titanium of $\beta$-TCP bone healing characteristics, which allowed fast bone formation around the implant. It was verified that the immature bone formation was increased in the experimental groups when compared to the control group. This agrees with Shiratori et al. ${ }^{5}$ (2005), who performed a study in femurs of rats to assess bone formation in defects filled with $\beta$-TCP through a histomorphometric analysis and assessment of the related mRNA bone protein expression. It was observed that the amount of newly formed bone tissue in the entire defect extension was significantly increased in the group where $\beta$-TCP was engrafted than in the control group (in which bone defects were not filled with $\beta$-TCP). According to the authors, the results showed that $\beta$-TCP is an appropriate material for osteoconduction, providing bone formation. Nakadate et al. ${ }^{14}$ (2006) assessed the characteristics of the newly formed bone tissue around dental implants, concomitantly inserted with tricalcium phosphate grafts. The osteogenesis was 
examined in two clinical relevant sites: the surface of biomaterial and the interface between biomaterial and implant. Reactive osteoclasts invading the area with biomaterial were observed and, shortly after, osteoblasts setting bone matrix into the region that was reabsorbed. Direct contact between bone tissue and the implant surface was observed by electronic microscopy. The results of our study suggest that there was direct contact between $\beta$-TCP and the titanium surface, providing faster bone formation in the areas where biomaterial was used.

\section{Conclusion}

Data from this work indicate that $\beta$-TCP may be useful in non-critical bone defects, promoting fast replacement by newly formed bone tissue, preventing soft tissue growth in the defect, and maintaining osteoconduction properties even when associated to commercially pure titanium.

\section{Conflict of interest statement}

The authors declare no potential conflicts of interest regarding the authorship and/or publication of this paper.

\section{Resumo}

Objetivo: O presente trabalho tem como objetivo fazer uma análise histológica descritiva do reparo de defeitos ósseos preenchidos com $\beta$-TCP associado a implantes de titânio puro, em cavidades confeccionadas em calotas cranianas de ratos. Materiais e método: Foram selecionados randomicamente 18 ratos, machos adultos e a seguir divididos em três grupos de seis ratos cada, de acordo com o período de morte: 15, 30 e 60 dias. Na calota craniana de cada rato foram confeccionados quatro defeitos ósseos preenchidos com: (a) $\beta$-TCP, (b) coágulo, (c) $\beta$-TCP + parafuso de titânio puro e (d) parafuso de titânio puro. As amostras foram cortadas e avaliadas histologicamente. Foi analisada a presença e volume de tecido conjuntivo frouxo e de tecido ósseo imaturo, bem como a presença ou ausência de material remanescente $(\beta-T C P)$ no defeito. Resultados: Verificou-se a aceleração do processo de neoformação óssea na presença do $\beta$ - TCP. Conclusão: Os resultados sugerem a biocompatibilidade e osteocondutividade do biomaterial, mesmo quando associado a implantes de titânio puro.

Palavras-chave: Biomateriais. Fosfatos de cálcio. Substitutos ósseos.

\section{References}

1. Yamada M, Shiota M, Yamashita Y, Kasugai S. Histological and histomorphometrical comparative study of the degradation and osteoconductive characteristics of $\alpha$ - and $\beta$ - tricalcium phosphate in block grafts. J Biomed Mater Res B Appl Biomater 2006; Part B: 139-48.
2. Jensen S.S, Broggini N, Hjørting-Hansen E, Schenk R, Buser D. Bone healing and graft resorption of autograft, anorganic bovine bone and $\beta$ - tricalcium phosphate. A histologic and histomorphometric study in the mandibles of minipigs. Clin Oral Impl Res 2006; 17:237-43.

3. Marx, RE, Stevens MR. Reconstruction of avulsive maxillofacial injuries. In: Fonseca RJ, Walker, RV, Betts NJ, Barber HD. Oral and Maxillofacial Trauma; 2.ed. Philadelphia: W.B Saunders Company, 1997, p.1101-203.

4. Schenk RK. Regeneração óssea: bases biológicas. In: Buser D, Dahlin C, Schenk RK. Regeneração Óssea Guiada na Implantodontia, Chicago; Quintessence books, 1996, p.49-100.

5. Shiratori K, Matsuzaka K, Koike Y, Murakami S, Shimono $\mathrm{M}$, Takashi I. Bone formation in $\beta$ - tricalcium phosphate-filled bone defects of the rat femur: Morphometric analysis and expression of bone related protein m RNA. Biomedical Research 2005; 26(2):51-9.

6. Hanawa T, Kamiura Y, Yamamoto S, Kohgo T, Amemiya A Ukai H, et al. Early bone formation around calcium-ion-implanted titanium inserted into rat tibia. J Biomed Mater Res 1997; 36:131-6.

7. Spiekermann H. Implantology: color atlas of dental medicine. New York: Georg Thieme Verlag; 1995.

8. Misch CE. Implantes Dentários Contemporâneos. 2. ed. São Paulo: Santos 2000. p. 451-467.

9. Merten, HA, Wiltfang J, Grohmann U, Hoenig JF. Intraindividual comparative animal study of $\beta$ and_ $\alpha$-Tricalcium Phosphate degradation in conjunction with simultaneous insertion of dental implans. J Craniofac Surg. 2001; 12(1):59-68.

10. Grandi G. Análise histomorfométrica comparativa entre $\alpha$ TCP e $\beta$-TCP / HA no reparo ósseo de calotas cranianas de ratos [Dissertação de Mestrado]. Porto Alegre: Faculdade de Odontologia da Pontifícia Universidade Católica do Rio grande do Sul; 2007.

11. Yuan H, Yang Z, De Bruij JD, De Groot K, Zhang X. Material-dependent bone induction by calcium phosphate ceramics: a 2.5 year study in dog. Biomaterials 2001; 22:2617-23.

12. Wei, D, Zhou Y, Jia D, Wang Y. Structure of calcium titanate/titania bioceramic composite coatings on titanium alloy and apatite deposition on their surfaces in a simulated body fluid. Surface e Coatings Technology 2007; 201:8715-22.

13. Li Y, Habibovic P, Yuan H, van den Doel M, Wilson CE, de Wijn JR, et al. Biological performance in goats of a porous titanium alloy- biphasic calcium phosphate composite. Biomaterials 2007; 28 : 4209-18

14. Nakadate M, Amizuka N, Li M, Freitas PH, Oda K, Nomura $\mathrm{S}$, et al. Histological evaluation on bone regeneration of dental implant placement sites grafted with a self-setting alpha-tricalcium phosphate cement. Microsc Res Tech 2006; 71(2): 93-104.

\section{Corresponding author:}

Roger Correa de Barros Berthold

Pontifical Catholic University of Rio Grande do Sul (PUCRS)

School of Dentistry / Block 6

Av. Ipiranga, 6681

90616-900 Porto Alegre / Rio Grande do Sul

Phone: 555133203562

E-mail: rogerberthold@hotmail.com

Recebido: 06/11/2013. Aceito: 03/05/2014. 